\title{
The Trends in Authentic Learning Studies and the Role of Authentic Learning in Geography Education
}

\author{
Nazan Karakaş-Özür ${ }^{1} \&$ Neşe Duman ${ }^{1}$ \\ ${ }^{1}$ Geography Department, Faculty of Letters, Çankırı Karatekin University, Çankırı, Turkey \\ Correspondence: Neşe Duman, Geography Department, Faculty of Letters, Çankırı Karatekin University, Çankırı, \\ Turkey.
}

Received: May 10, 2019

doi:10.5539/ies.v12n12p28
Accepted: September 2, $2019 \quad$ Online Published: November 29, 2019

URL: https://doi.org/10.5539/ies.v12n12p28

\begin{abstract}
Schools are the basic environments where learning takes place. The quality of these environments and acquirement of the knowledge and skills expected by societies have caused the disconnection between real life and the school. One of the main subjects of education circles in the 21 st century has been what to do in order to ensure the connection between real life and education. In this context, the subject of the study is the authentic learning strategy which aims to bring real life subjects and students together. Although this strategy was first introduced in studies conducted in the United States of America in the 1990s, its philosophical roots go back to the 19th century. According to authentic learning, students' encounter with real life situations or subjects in learning will be effective in raising effective citizens and increasing the quality of learning. The study focuses on how authentic learning is shaped in the literature and what place it takes in the Geography Curriculum of the Ministry of National Education (MoNE, 2018). The main features of authentic learning were determined, and a template was developed by means of the document review method and descriptive content analysis technique. The suitability of this template for the features was examined by reviewing the acquirements with the application principles of the GC 2018 and the explanations in the introduction section. In conclusion, it was determined that all the features required for authentic learning are present in the GC.
\end{abstract}

Keywords: authentic learning, authentic learning literature, geography curriculum, geography education, learning strategy

\section{Introduction}

\subsection{Introduce the Problem}

The New Education begins with the wind of John Dewey in the early twentieth century. It is also clear that when the change becomes inevitable for societies as a result of the increased speed of change, the static structure of traditional education does not prepare students for life anymore. To this end, all stakeholders of education have attempted to make the expected outputs of education compatible with the necessities of the time. The number of students and schools increased when states began to subject their citizens to compulsory education from a young age. While schools are involved in the process of preparing people for the areas in which they will contribute to society in their adult life, they have started to be prioritized rather than the real life itself. This has gradually led to the emergence of knowledge-laden individuals who focus on theory. The new education has advocated the idea "Education is not a preparation for the future life, it is the life itself (Dewey, 2010a, p. 3)" in the process which has been continuing since the beginning of the twentieth century. In this context, a discussion of the effectiveness of the school has emerged as it is the place where educational components come together.

This study will focus on authentic learning that derives its foundations from constructivism. Although authentic learning is not very new in terms of the roots of the idea, the systematics applied in schools are based on 20th-century educational studies. It is defined as a learning strategy used in constructivist and active learner classes while it is simply identified with apprenticeship education (Bektaş \& Horzum, 2010, pp. 12-13). Since the concept is still evolving, it is primarily necessary to define and identify the basic characteristics. In this context, the definition of the concept, its features, its application and its role in geography education were revealed.

\subsection{What is Authentic Learning?}

The most dominant meanings of this word used in all three languages are the expressions of "real and genuine." As 
an educational science term, authentic learning has been put forward in order to emphasize these expressions, namely the real and the genuine. Its meaning used in everyday language, such as authentic dresses, authentic patterns, which refer to the local, has nothing to do with this educational concept. The idea of authentic learning, of which theoretical and philosophical roots go back to Jean-Jacques Rousseau (1712-1778), emerges as a reaction to the increasingly weakening ties between education and real life. In response to the criticism that the students who have undergone a certain education process cannot solve their real life problems, and that the knowledge they have learned does not go beyond theory, it is demanded that learning should be real and genuine, in other words, should include the life itself. This idea, which developed in the historical process, gained a systematic order with the standards regulated by Newman et al. in the early 1990s. With this study, 5 standards were introduced for authentic learning. 1) High-order thinking, 2) Profound knowledge, 3) Connection to the world outside the classroom, 4) Continuous communication, 5) Community support in student achievement (Newmann \& Wehlage, 1993, p. 9). The idea that changing the teaching methods and techniques in schools will solve many problems, including the problem of moving away from the real life (Özden, 1996), has become effective in the acceptance of these standards for the teaching process. In particular, those who adopt constructivism in education have argued that authentic learning will be effective in educating individuals who are lifelong learners and can solve real-life problems with what they have learned. The fact that constructivism defines learning as an interpretative, regulatory and non-linear construction process resulting from the interaction of students with their environment and the physical and social world (Fosnot, 2007, p. 38) corresponds with the emphasis on the reality in authentic learning.

The definition of authentic learning as a concept will be possible with its evaluation from many aspects. First and foremost, as a learning strategy, what authentic learning aims at brings along the formation of some basic principles. "The aim of authentic learning is not to learn the subject directly but to produce solutions to real-world problems. In this process, authentic learning begins with authentic tasks and continues with authentic activities and evaluations. In the authentic learning process consisting of tasks, activities, and evaluations, the teacher is the guide and students are active participants (Koçyiğit \& Zembat, 2013, p. 292).” If we summarize the purpose as teaching the real world, the application of this purpose is realized in a space starting from the student's environment (Bektaş \& Horzum, 2010, p. 17). In this case, learning environments designed within the real world are required. That is why authentic learning is defined as a form of “....cognitive apprenticeship (Quigley, 2014, p. 121)." In line with the common features observed in these definitions, authentic learning is a learning strategy that is carried out using real life problems, situations or environments in which students are made active. This strategy consists of a large number of components in terms of the environment used, the situations/subjects and the roles of students and teachers. For example, learning environments may be outside the classroom, sometimes a road junction, a shopping center, a park, a laboratory, a mining site, or just home. The environments required by the authentic task are determined as the working area of students. At the same time, the fact that these environments are real environments where people live leads to the diversification of the social environment consisting of teachers and students in the classroom. The main components compiled from the literature are presented in a diagram to reflect this diversity (Table 1).

Table 1. Components of authentic learning (Compiled from Bektaş \& Horzum, 2010, p. 10)

\begin{tabular}{l}
\hline Authentic context \\
Authentic activity/task \\
Multiple perspectives and roles \\
Expert performance \\
Cooperation \\
One-to-one training \\
Reflection \\
Speak clearly \\
Authentic assessment \\
Structured support \\
\hline
\end{tabular}

The design principles of the authentic learning strategy can be summarized as follows (Figure 1). 


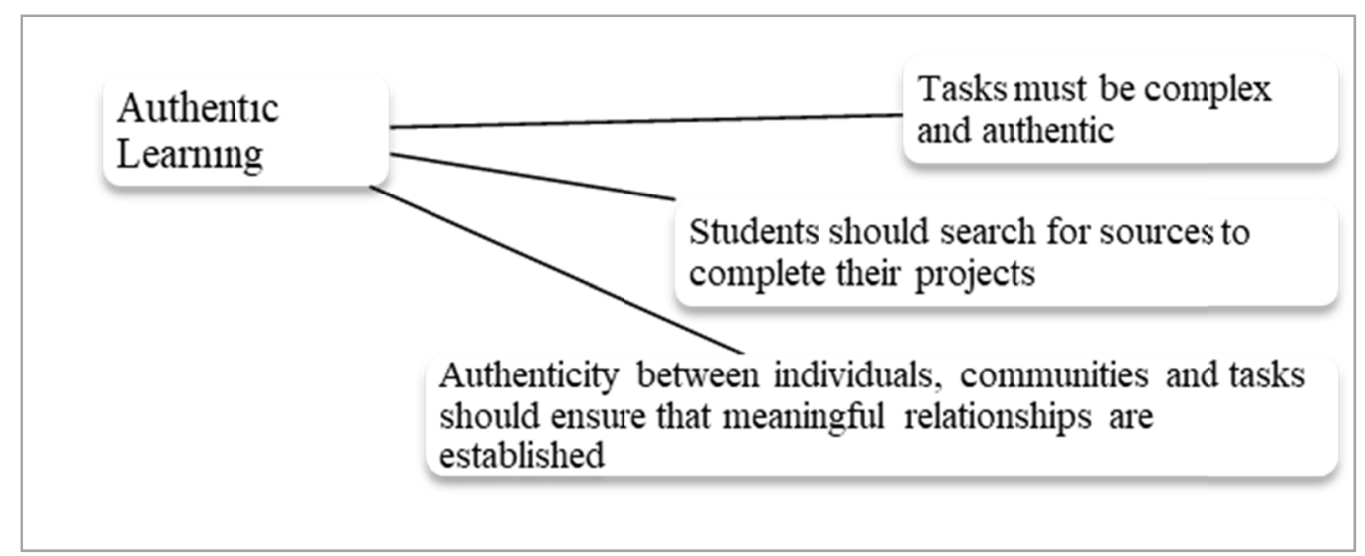

Figure 1. Design principles of authentic learning (Compiled from Bektaş \& Horzum, 2010, p. 10)

When designing authentic learning environments, the problem should be sufficiently complex, just as in real life. While these and similar examples are already experienced in the routines of everyday life, the fact that it has become the subject of the practices that Newmann et al. carried out implicitly with the lessons in the school environment created authentic learning (Newmann \& Wehlage, 1993). In addition to the design principles that define the students' situation, authentic learning has features regarding the learning environments and elements. These features also have determinative qualities that will also affect the shaping of practices. The general features of authentic learning were examined in 3 separate dimensions. These are the student's role, the practice and the environment, the status and the subject, and the features for each field are listed separately (Figure 2).

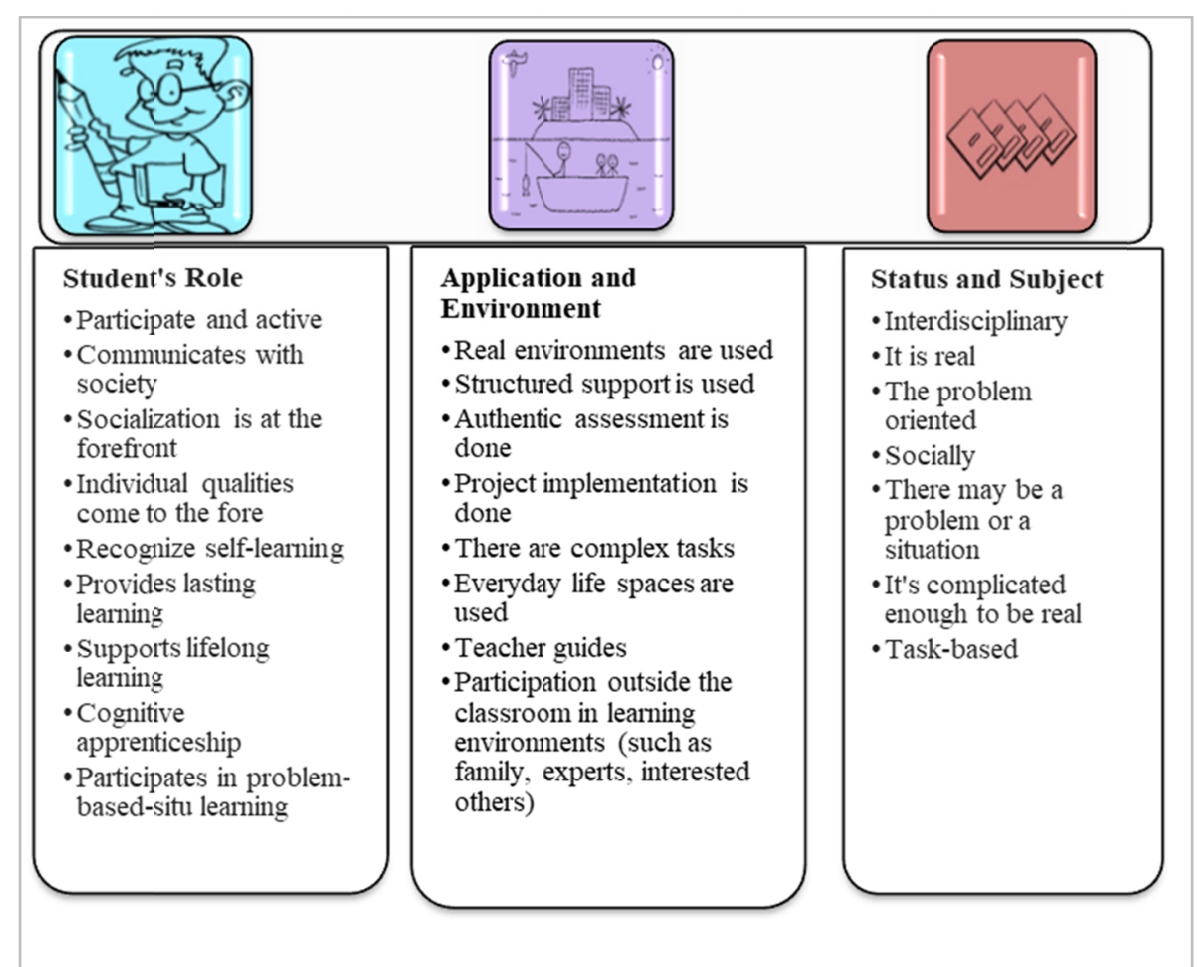

Figure 2. Basic Features of Authentic Learning (The content of the figure was created by reviewing the literature given here: Newmann \& Wehlage, 1993; Smeds, Jeronen, \& Kurppa, 2015; Göçmen, 2004; Moffett, 2012; Öner, 2018; Rule, 2006; Westberg \& Leppien, 2018; Webster-Wrights, 2009; Preus, 2012; Maina, 2004; Quigley, 2014; Slepkov, 2008; Hillis \& Calderhead, 2009; Wilson \& Schwier, 2009; Akpınar, 2004; Gürdoğan \& Aslan 2016; Boyacı \& Güner, 2017; Cox et al., 2009; Dilmaç \& Dilmaç 2014; Önger \& Çetin, 2018; Koçyiğit \& Zembat, 2013; Karakuş, 2012; İneç \& Akpınar, 2017; Huang, 2011; Way \& Eathough, 2008; Smeds, Jeronen, \& Kurppa, 2015; Borthwick et al., 2007; Oliver et al., 2007; Brickell \& Harrington, 2006; Horzum \& Bektaş, 2012) 
The active and participatory role of the student is realized by solving real life problems and at the same time taking on complex tasks as stated in the design principles. In a sense, the student has the opportunity to complete the education process without leaving the context of his/her life. In this way, the relationship between the knowledge learned in the ordinary course of life and the knowledge learned in school is established. The most important benefit of this is that the knowledge learned becomes permanent. Students may think about the problems that may arise from the absence of sunlight in the house they live in and the problems that may arise if there is no pharmacy nearby. They also face the real problems of the world, which is the common house of people, when they consider the connection of the oil released from the ship that sank in the Atlantic Ocean with the Mediterranean ecosystem, the effects of the extinction of insects on the food chain or the effects of the melting glaciers on the vegetation in the world. The influx of refugees that emerged as a result of a war can lead them to the migration of tribes in the history lesson. Thus, as spatial and temporal scales expand, the real problems experienced by people are addressed by determining an authentic strategy. The definition, the firsts and the basic features of authentic learning also provide clues to the process of implementing this strategy.

In addition to the many features of authentic learning that are considered to be useful in practice, some warnings should also be considered. For example, Smeds, Jeronen, and Kurppa who said, "An authentic learning environment is not "lapis filosophorum (The legendary stone that is thought to turn anything it touches to gold) to solve learning difficulties," have warned that new learning strategies still have problems that they cannot solve despite all the positive aspects $(2015$, p.400). In this context, it is clear that education will bring different difficulties especially when it is designed as student-centered. For example, preparing a work plan with actual subjects in the context of everyday life, taking into account each student, means increased working hours and workload for the teacher. Life problems used in practice may be challenging for students. By directing them from simple to complex or small clues, the teacher will play a guiding role. The context in authentic learning can be the problem created, the event, the situation, the concept, the practice or the work task. Advertisements on television, information notes prepared by public institutions for citizens, construction of parking areas, or endangered animals are the main context situations to be selected according to the lesson and subject. Occasionally, insects that cause disease can be the authentic subject of the lesson when investigating the quality of a place. In order to identify real-world contexts that can vary from primary education to university education, the teacher needs to know very well about authentic learning and its practices. What distinguishes authentic learning from other active learning practices, in which students are made active in the classroom, is the use of real learning objects. Thus, the authentic learning process emerges within the framework of the above-mentioned features (Figure 3).

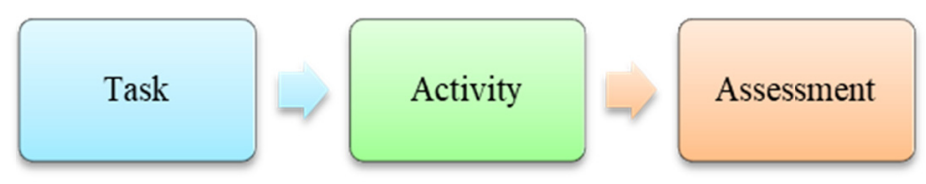

Figure 3. Authentic learning process in practice

\subsection{Geography Education and Authentic Learning}

Geography is a science in which space is examined. Subjects falling within the field of geography in education are given through geography, life science, science and social studies lessons. The teaching of these subjects is important not only in terms of content knowledge but also in solving problems that students will face in their future lives. To acquire geographical awareness has been brought to forefront among the main objectives of geography education (MoNE, 2018). In this context, the recognition of space, teaching it in a memorable way, and raising geographical awareness have been considered extremely important. Authentic learning was examined with its all aspects above. Geography education to be discussed in this study covers the field of geography science, which is an ancient science. Its basic concepts were determined as scale, space, location, landscape, environment, region, location, distribution, spatial interaction, and change (Öztürk, 2007, pp. 16-31). When these concepts are examined, they appear to be parallel with many features indicated in authentic learning. For example, it is recommended to first start from the place where students live while teaching map skills to them (Demiralp, 2009, p. 958). The starting point for the skills related to space, which is a very important part of geography, is also the student's daily life (Ünlü \& Yıldırım, 2017, p. 18). It is of primary importance to understand and recognize space for the use of space in terms of place, direction, and location and for the association of features in space. In brief, the daily life of the student is a valuable tool in teaching geography. What makes authentic learning effective is that 
it is based on the student's daily life and the real problems faced.

Since geography has an area of knowledge given at all levels from pre-school education to primary, secondary and higher education, it requires the use of various strategies, methods, and techniques. At the same time, the value of this education for people and society is frequently emphasized in publications on geography education (Karabağ \& Şahin, 2007; Özey \& İncekara, 2010). Another aspect of geography that is deemed valuable in relation to the subject is the task of introducing the world in which the human being lives. Since this introduction focuses on the real itself, a situation, associated with the basic features of authentic learning, emerges. Geography, which evaluates both human beings and their activities in the context of the relations with the space, is an area in which it is possible to apply authentic learning easily. The changes in geography after the 1960s resulted in highlighting the emphasis on reality in scientific studies (Öztürk, 2007, p. 14). The reflection of this thought trend on geography education has become inevitable. The idea of bringing more real-world problems to the classroom, which supports this idea, prepares a favorable ground for authentic learning.

\section{Method}

The study focuses on the concept of authentic and its role in the Ministry of National Education Geography Curriculum (MoNE, 2018). The fact that authentic learning is new in the world has led to the need to investigate the situation in Turkey. The first studies on the subject were conducted in the United States of America in the early 1990s. In the same years, it became the subject of the widescale applications (Newmann \& Wehlage, 1993). The definition, characteristics, and principles of the concept were determined for the first time in the USA with both theoretical and practical studies. The authentic learning strategy which is new and not popular generally in education in Turkey, especially in geography education, should be first discussed as a phenomenon. For this purpose, the phenomenology design was used in the study. The phenomenology design presents examples, explanations, and experiences that will help to understand a phenomenon better (Yıldırım \& Şimşek, 2013, p. 81). The method of design is a document review, and in this way, the common concepts and features related to the subject are revealed. The related studies were examined in accordance with the determined purposes, and the data obtained were analyzed with the descriptive content analysis technique (Günay \& Aydın, 2015; Kozikoğlu \& Senemoğlu, 2015). This technique includes "the evaluation of the studies on a specific topic and assessment of the trends and research results in a descriptive dimension" (Çalık \& Sözbilir, 2014, p. 34). Therefore, the literature review of the first sub-problem of the study was carried out. The introduction of the concept of authentic learning into education systems created slightly differentiating perspectives. In this context, a content analysis was performed on the explanatory texts related to the objectives and implementation of the MoNE GC for the association mentioned in the second sub-problem. Thus, the features of authentic learning, which were determined by using the literature, were examined in the introduction text of the MoNE GC. The problem situation and model of the study are as follows (Table 2).

I. How was the place of authentic learning in the literature and geography education shaped?

I.1. How is authentic learning defined in the literature?

I.2. What is the relationship of authentic learning with the Geography Curriculum of 2018 ?

Table 2. Research model

\begin{tabular}{|c|c|c|c|c|c|}
\hline Problem & Pattern & Method & Technique & & Data \\
\hline $\begin{array}{l}\text { I. How was the place of authentic learning in the literature } \\
\text { and geography education shaped? }\end{array}$ & \multirow{3}{*}{ 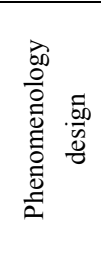 } & \multirow{3}{*}{ 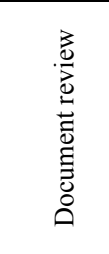 } & \multirow{3}{*}{ 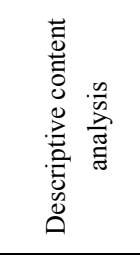 } & \multirow{3}{*}{ 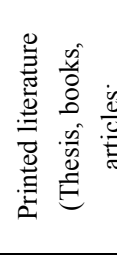 } & \multirow{3}{*}{ 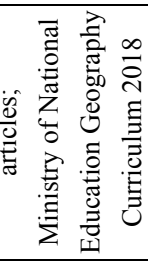 } \\
\hline Sub-problems & & & & & \\
\hline $\begin{array}{l}\text { I.1. How is authentic learning defined in the literature? } \\
\text { I.2. What is the relationship of authentic learning with the } \\
\text { Geography Curriculum of } 2018 \text { ? }\end{array}$ & & & & & \\
\hline
\end{tabular}

The study process consists of the literature obtained as a result of scanning from the scanning fields such as Google Scholar, the Council of Higher Education thesis database, ERIC, EBSCO with the keyword of authentic learning, which was started on 03.06.2018 and completed on 01.09.2018. Almost all of the literature to be used in the study was obtained from web scanning, while some were obtained from libraries by using the bibliographies of publications. A total of 49 studies were examined during the review with regard to the subject. The studies were categorized according to their types and analyzed from various angles. All of the theses mentioned in the table and 1 book are the studies conducted entirely in Turkey, and in addition to all other studies conducted in Turkey, there 
are other studies outside Turkey among the other group of articles. The list of these studies is given in Appendix A and Appendix B at the end of the study. 1 book, 28 articles, and 19 graduate theses were reached in the review conducted with the keyword of authentic learning. Many studies were found in the foreign literature on authentic learning and authentic tasks. The publication of a journal in the United States of America in 2004(See Journal of Autentic Learning) which is specific only to this field, has become an important factor increasing the number of publications on the subject. Among the publications, the inclusion of 18 English articles that are appropriate for the purpose arises from the difficulty in identifying the features of the concept from the studies conducted in Turkey and the need to create analysis themes for the MoNE GC. 1 book, 10 articles and 19 graduate theses published in Turkey and in Turkish constitute the remaining literature.

In descriptive content analysis studies, it is important to determine the unit in which the content will be analyzed (Yıldırım \& Şimşek, 2013, p. 229). For this purpose, the themes were chosen as the analysis unit according to the purpose of the study. In descriptive content analyses, it was suggested to define the process and specify the analysis units in terms of the reliability and validity of the technique (Çalık \& Sözbilir, 2015, p. 35). Accordingly, the analysis units determined for the two sub-problems of the study are given in the table (Table 3). Expert opinions were received in relation to the analysis units determined, and $99 \%$ concordance was determined between the codes of the two experts.

Table 3. Descriptive content analysis themes of the study

\begin{tabular}{l}
\hline Thesis and book themes \\
\hline Area \\
Type \\
Approach \\
Method \\
Place of publication \\
\hline MNE GC Themes \\
\hline Student's role \\
Application and environment \\
Status and subject \\
\hline
\end{tabular}

\section{Results}

The research results are presented under two separate headings according to the sub-problems.

\subsection{Results Related to the First Sub-Problem}

The first sub-problem of the study is the question of how authentic learning is defined in the literature. In this context, it was attempted to determine which aspects of authentic learning were addressed in the total of 49 studies in the literature reviewed. Related literature, theses, and articles were grouped and examined. Articles and theses were evaluated by classifying them in terms of the related field, approach, method, and place of publication.

14 of the articles examined are related to educational sciences. Only 5 of them are descriptive studies aimed at defining the concept of authentic learning directly. According to the chronology, they are the studies of Newmann and Wehlage (1993), Maina (2004), Rule (2006), Webster-Wright (2009), and Quigley (2014). The remaining 9 studies are applications on special subjects such as farming training, outdoor training, and special training in fields such as primary education and higher education. In the literature, it was stated that all of these applications gave positive results (Appendix A). The issue to be highlighted here is that no article in the field of educational sciences in Turkey and in Turkish was reached in both descriptive and applied approaches. The lack of literature in this field is an important finding in terms of the expectation of revealing the various aspects of the concept, determination of its principles and features, and producing theoretical knowledge for practitioners with discussions. 
Table 4. Results related to the articles examined

\begin{tabular}{|c|c|c|c|c|}
\hline Area & Approach & $\mathrm{f}$ & Method & $\mathrm{f}$ \\
\hline Educational Sciences & Descriptive/Applied & $5 / 9$ & Document/Experimental & $14 / 0$ \\
\hline Language Education & \multirow{8}{*}{ 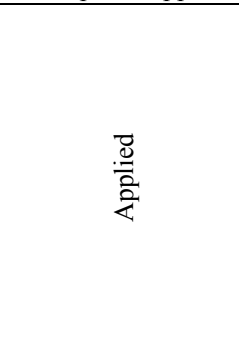 } & 3 & \multirow{8}{*}{ 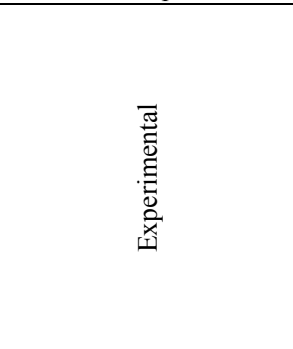 } & 3 \\
\hline Social Studies Education & & 3 & & 3 \\
\hline PSETE* & & 3 & & 3 \\
\hline Geography & & 1 & & 1 \\
\hline Mathematics Education & & 1 & & 1 \\
\hline History Education & & 1 & & 1 \\
\hline Science Education & & 1 & & 1 \\
\hline Visual Arts Education & & 1 & & 1 \\
\hline Total & & & & 28 \\
\hline
\end{tabular}

*PSETE: Pre-school and Elementary Teacher Education.

All of the studies in fields other than educational sciences mentioned in Table 4 are experimental studies. 10 of the experimental studies were published in Turkey, 18 of them were published outside Turkey. The studies conducted outside Turkey consist of subjects such as mathematics, geography and management science, and the application results of all of them state that the authentic learning strategy has a positive effect on learning (Appendix A). Turkish publications included in the reviewed literature are all the publications that could be reached. The selection made in the publications in English according to the purpose was not made for these publications due to the small number of Turkish publications. When the articles are evaluated according to their fields, the first ones that draw attention are social sciences, pre-school and primary school teaching and language education. Apart from these fields, only 1 article was reached from geography education and visual arts education. It is noteworthy that authentic learning in the field of social sciences education in Turkey is more frequently investigated compared to other fields. The multidisciplinary structure of social sciences education seems to be compatible with the interdisciplinary feature of authentic learning that needs to be studied. The first article on this subject in Turkey was published by Akpınar (2004). This study was then followed by the studies of Karakus (2012), Horzum and Bektaş (2012), Koçyiğit and Zembat (2013), Dilmaç and Dilmaç (2014), Gürdoğan and Aslan (2016), İneç and Akpınar, (2017), Öner (2018), Önger and Çetin (2018). As can be seen, in the last two years, three articles in the fields of social sciences and geography addressed this issue. This indicates a slight increase compared to other fields. The results of all 10 articles prepared in the applied approaches are stated as positive. In the lessons carried out using the authentic learning strategy, it was concluded that attitudes towards the lesson and success increase, and it was suggested to spread these applications. Further information on the subject can be found in the articles given in Appendix A.

Graduate theses contribute significantly to both theoretical framework and application accumulation of science fields. From this aspect, the subject of authentic learning in graduate theses is also included in the literature review. A total of 19 theses were found in the thesis database of the Council of Higher Education (Appendix B). These theses were divided according to their fields and various features. Accordingly, there are theses related to mathematics education in the first place in terms of number (Table 5).

Table 5. Results related to the theses

\begin{tabular}{|c|c|c|c|c|c|}
\hline Area & Type & $\mathrm{f}(\mathrm{PHD} / \mathrm{MA})$ & Approach & Method & Public. place \\
\hline Mathematics Education & \multirow{10}{*}{ PHD/MA } & $3 / 1$ & \multirow{10}{*}{$\frac{\overrightarrow{0}}{\stackrel{.0}{0}}$} & \multirow{10}{*}{ 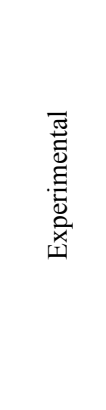 } & \multirow{10}{*}{ 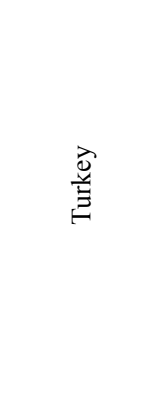 } \\
\hline Educational Sciences & & $4 / 1$ & & & \\
\hline Science Education & & $1 / 1$ & & & \\
\hline Language Education & & $2 / 2$ & & & \\
\hline Elementary Teacher Education & & $-/ 1$ & & & \\
\hline Geography Education & & $-/ 1$ & & & \\
\hline Life Science Education & & $1 /-$ & & & \\
\hline Social Studies Education & & $1 /-$ & & & \\
\hline Total & & $12 / 7$ & & & \\
\hline General Total & & 19 & & & \\
\hline
\end{tabular}


7 of the theses are in the field of postgraduate studies, and 12 of them are in the field of doctorate. When the theses were divided according to their fields, there were also 4 theses in the field of mathematics education and 4 theses in the field of educational sciences, 2 theses in the fields of science education, 2 theses in the fields of English language and Turkish language education, 1 thesis in the fields of primary school teaching, geography, instructional technologies, life sciences and social sciences education. The first thesis produced in Turkey regarding authentic learning belongs to 2010. Furthermore, it was observed that it has not only started to be studied recently but has not been examined sufficiently in terms of the fields in addition to the small number of studies. All theses consist of applied approaches and are prepared with experimental methods. Studies concluded that authentic learning practices increase the success of the lesson and the attitude towards the lesson. In this context, it is clear that the use of the authentic learning strategy in education will give positive results. However, the small number of studies in general and the lack of distribution among fields suggested that studies should be increased and diversified in different fields. The relevant literature was added to the end of the study (Appendix B).

The authentic learning practices related to geography education in the literature examined show the concordance of authentic learning thought with the structural features of the field. Brickell and Herrington (2006) used the authentic learning strategy in geography education with a project that they developed. The Project of Geography Initiative conducted with the collaboration of Sydney Olympic Park Management, Department of Educational Sciences, Metropolitan Catholic Education Bureau and Wollongong University is a real life problem related to the management of a park. The students were asked to design the management of the park. While specializing in geography, the students solved the real life problem, and at the same time developed sensitivity to environmental problems. The study reached the expected results, so that a path from real life to geographic knowledge was followed (Brickell \& Herrington, 2006, p. 544). Alacahan (2016) stated that "another dimension of authentic strategies in teaching geography is authentic situations hidden in geographic knowledge." At this point, it is clear that teaching local knowledge in geography is a part of this strategy as an authentic context element. In the study of Alacahan (2016), which defines the local geographic knowledge, the local geographic knowledge was evaluated as an authentic material, and an applied study was carried out on primary school students. In the study, local geographical knowledge was limited to the title of the public calendar. In this application performed in primary education, it is underlined that the transfer of local geographical knowledge to younger generations decreases and this knowledge starts to be forgotten. Although some of this knowledge has no scientific basis, it is also stated that it should be protected as they are part of the culture. Another geographer Öner (2018) conducted a study on local geography education. This refers to the features of the location in the immediate vicinity of the student as the locality. Öner described the local geography education as follows: "In particular, it is a teaching approach which, as a part of the education process in general and geography education in particular, helps the individual to understand his/her basic environment and region, starting from his/her immediate environment (p. 118)". The researcher also explains its application as follows: "In local geography education, it is necessary that students in primary school, secondary school, secondary education, and higher education examine the geographical factors in their residence and immediate environment (p. 119)". As understood from this definition and from the definitions described above, authentic learning and local geography education are not identical. While local geography education is an understanding, authentic learning is a learning strategy. In addition to these two studies, which were conducted in relation to authentic learning that is a very new concept, no other study was reached in geography. However, it is clear that geography has very rich content in terms of authentic learning strategies. For example, even materials that can be connected to real life such as bus timetables, city maps, and diaries can be used in authentic geography education (Rule, 2006, p. 7). However, the place of authentic learning in geography education in Turkey remains a topic not yet discussed.

Finally, there is only one book in the literature in Turkey about authentic learning. The book prepared by Bektaş and Horzum was published in 2010 in a small size and consists of 88 pages. The book is a compilation study aiming to define authentic learning. The fact that the work is unique in the field and that no other works were published in the intervening period increase its value. The study is the only reference source with its theoretical and descriptive nature. It has become one of the main sources in this study.

\subsection{Results Related to the Second Sub-Problem}

Another field of study on authentic learning practices in geography education is curricula. In Turkey, the efforts to bring innovation in education since the 1980s have taken shape in various ways. After the 2000s, the focus shifts to learning and teaching, which are among the most fundamental components of education. Cognitive learning theories come to the fore especially by emphasizing how to teach rather than what to teach. The GC, of which foundations were laid in 2005 and which was lastly revised in 2018, brings to the fore the acquirement of skills. At the same time, it is desired to give some values. These values are given in the program as guiding notes for teachers 
together with the related acquirements. Furthermore, the encounter of students with real life problems in order to gain knowledge, skills, values, and attitudes is clearly stated in the application principles of the program.

First of all, one of the reasons for preparing the program which was put into practice in 2005 was explained as increasing the associations with daily life. "The emphasis on the use of information and communication technologies that take place in every area of our lives in geography education and the relationship of acquirements with the daily life was increased (MoNE, 2018, p. 11)". Since the subjects of geography involve the relationships between space and human, it will not be difficult for this science to associate the cognitive contents with real life. The association of the wide range of geography from natural sciences to physical sciences with many sciences ensures the adaption to the multidisciplinary perspective of authentic learning.

In this study, the text which contains explanations related to the application in the introduction of the curriculum was subjected to the content analysis in terms of student's role, application and environment, and situation and subject themes. The findings were compared with the features of authentic learning (Table 6, 7, \& 8). The situations corresponding to the features are indicated by the $\sqrt{ }$ sign and are then explained with exemplary citations. In some cases, the ! sign used indicates situations which do not fully correspond to the features and in which the MoNE GC is more inclusive. The warnings shown with this sign are explained in the relevant fields.

Table 6. Authentic learning regarding the role of the student and its comparison with the MoNE (2018)

\begin{tabular}{llcc} 
& Student's Role & Match & Not Match \\
\cline { 2 - 4 } & Participate and active & $\sqrt{ }$ & - \\
Communicates with society & $\sqrt{ }$ & - \\
Socialization is at the forefront & $\sqrt{ }$ & - \\
Individual qualities comes to the forefront & $\sqrt{ }$ & - \\
Recognize self-learning & $\sqrt{ }$ & - \\
Provides lasting learning & $\sqrt{ }$ & - \\
Supports lifelong learning & $\sqrt{ }$ & - \\
Cognitive apprenticeship & $\sqrt{ }$ & \\
Participates in problem-based-situ learning & $\sqrt{ }$ &
\end{tabular}

The features of authentic learning and the features of the MoNE GC were compared in terms of student, environment and situation/subject. In the MoNE GC, it is aimed to provide students with three groups of skills, namely, personal, social and geographical skills. In addition to these skills, the use of modern educational methods, which will enable students to recognize their own learning and make them active by providing permanent learning, is demanded (MoNE, 2018, pp. 7-8). Thus, the role of students in authentic learning seems to be compatible with the student roles in the MoNE GC (Table 6).

The second article of the program implementation principles is as follows: "In the transfer of the subjects in the 2nd curriculum, activities and studies that enable the association with other disciplines and daily life should be included" (MoNE, 2018, p. 15). The program structure, which consists of 4 separate units for each grade level, covers the continuation of these units spirally in the 9th, 10th, 11th and 12th grades. Below the units, there are brief descriptions of the unit, acquirement statements, values and skills sections. At the same time, the program acquirement statements provided limitations and directions with the explanations when necessary. For example, as an explanation of the acquirement of "9.1.1. Explains nature and human interaction with examples", the expression of "a) Examples are given from the world and Turkey" was added. Another issue emphasized in the program is the values and skills associated with the acquirements. The sections matched with the acquirement numbers such as “Geographic Skills: Geographical inquiry (acq. 9.3.1, 9.3.2, 9.3.3), Map skills (acq. 9.3.1, 9.3.2, 9.3.3)" and "Values, Responsibility (acq.10.1.11, 10.1.14), Patriotism (acq.10.1.14, 10.1.17)" were placed under the units as needed. These directions sometimes refer to the student and sometimes to the application and environment. The features of the application environments are specified in the explanations section of the MoNE GC. 
Table 7. Authentic learning regarding the application and environment and its comparison with the MoNE (2018)

\begin{tabular}{llcc} 
& Application and Environment & Match & Not Match \\
\cline { 2 - 3 } & Real environments are used & $\sqrt{ } !$ & - \\
Structured support is used & $\sqrt{ } !$ & - \\
Authentic assessment is done & $\sqrt{ }$ & - \\
Project implementation is done & $\sqrt{ }$ & - \\
There are complex tasks & $\sqrt{ }$ & - \\
Everyday life spaces are used & $\sqrt{ }$ & - \\
& Teacher guides & $\sqrt{ }$ \\
& Participation outside the classroom in learning environments (such as family, & $\sqrt{ } !$ \\
experts, interested others) & & \\
\hline
\end{tabular}

Geography plays a very important role in education as a spatial science. Therefore, the teaching of real environments is frequently emphasized in the MoNE GC starting from the immediate environment. In accordance with the purposes of the geography program, the new program requires geography lessons to be associated with real life (MoNE, 2018, p. 11). In the section related to the learning-teaching approach in the program, the expression of "moving the classroom to the field" is included. The heading of the points to be considered in practice include the warnings of the comparison of the student with real events, and the use of places outside the school (MoNE, 2018, pp. 13-14). Thus, it was observed that all subjects listed in authentic learning were covered by the MoNE (2018, pp. 13-14). Location information in the modern world is also available in digital environments. This is an important convenience that brings real life situations to the classroom in a way that the student can use. The use of geographic information systems (GIS) in geography education is suggested by the MoNE GC. The examples of the use of GIS with the authentic learning strategy in geography education gave positive results (Brickell \& Herrington, 2006, p. 544). The expression of "real environments are used" in Table 7 is evaluated in this respect. Here, carrying out the majority of geography lessons in the classroom seems to be in contradiction with the expression of "real environments are used." However, this problem can be resolved by occasional land trips, field work, and the use of GIS data in the classroom. In addition, the activities intended to be prepared in the program may support the structured support, and the invitation of suggested experts to the classroom may support the external participation. The warning signs in the first two and the last items in Table 7 should be evaluated together with these explanations. The expected features in these items can be easily transformed into an authentic learning strategy application through the activities to be performed in the lessons.

Table 8. Authentic learning regarding the situation and subject and its comparison with the MoNE (2018)

\begin{tabular}{|lccc}
\hline & Status and Subject & Match & Not Match \\
\cline { 2 - 4 } & Interdisciplinary & $\sqrt{ } !$ & - \\
It is real & $\sqrt{ }$ & - \\
The problem oriented & $\sqrt{ }$ & - \\
Socially & $\sqrt{ }$ & - \\
There may be a problem or a situation & $\sqrt{ }$ & - \\
It's complicated enough to be real & $\sqrt{ }$ & - \\
\hline
\end{tabular}

In the comparison of situation and subject, the item of interdisciplinarity between the program and the authentic learning feature, which is not fully compatible with each other and which is indicated with a warning sign, appears to be compatible with the structure of the so-called sciences community related to geography, which is essentially between social sciences and physical sciences (Özçağlar, 2011, p. 2). Therefore, although the geography lesson seems to point to a single science, the structural features of science are transitive in close contact with other disciplines. The examination of different lesson groups or science fields indicated by multidisciplinarity in authentic learning with a combination of problems can be achieved significantly by this feature of geography. The MoNE GC, especially underlining this issue, states the association with other disciplines in the lessons in the 2nd article under the heading of points to be considered in practice (MoNE, 2018, p. 13). For example, in terms of cause and effect relationship, drought is related to human sciences as much as natural sciences. Drought among the subjects of geography lessons is addressed with this broad perspective. The MoNE GC requires the use of constructs called activities in the lesson. These constructs correspond to the tasks and projects in authentic 
learning. The purpose of activities was to ensure the teamwork of students with each other, to make a comparison with real life problems and to make designs at different levels of difficulty (MoNE, 2018). Authentic learning also has similar features in terms of subject and situation.

\section{Discussion}

Authentic learning emerged as a concept in America in the 1990s and became widespread and was developed with applications in a short time. In Turkey, the concept is not well known yet, and it is observed that the related practices are limited. It was found important to reveal the basic principles, components and application features of authentic learning instead of making a single definition. According to this, it was determined that the most important expression that defines authentic learning is reality and this reality spreads to the whole world from the immediate environment. Every event, situation or place, which occurs not only as local elements but also as a part of the world at longer distances, can be the subject of authentic learning. At the same time, as much as the person or the individual himself, societies fall within the subject area. The occurrence of events in the past or today, provided that the space is real, does not constitute an obstacle to becoming an object of authentic learning.

Real spaces are also used, apart from real events, in authentic learning practices. In this context, learning goes outside the classroom, and streets, parks, factories, natural environments and sometimes the web become a learning environment. In this diversity, lessons are often shared with experts in other fields while the teacher plays a guiding and sometimes facilitating role. Students communicate with their environment while doing their works and share the results of their works with their families, being in the first place, and relevant persons. This social environment confirms the theories supporting that learning will be strengthened by means of the interaction with the social environment. In general, the practices performed indicate that students' progress in the acquirement of skills and permanent learning, and develop positive attitudes towards the lesson. Sometimes structured support is given because real life problems in practice have various degrees of difficulty. Thus, it is ensured that students gain experience to solve the next problem with a higher degree of difficulty. As students continue their works, solve the problem they encounter and experience its consequences, a situation that makes learning meaningful emerges.

Geography education generally involves the introduction of the world from all aspects. Although this was the case from past to present, the fact that this expression includes an exact reality in the last half-century has started to be the main point. This trend, which is generally observed in all sciences, especially in geography, provided a focus on the real knowledge to be used in problem-solving. Thus, authentic learning is considered to be a very useful strategy for geography education, of which the main subject is space and humanity. Authentic learning, especially recommended for multidisciplinary studies, provides holistic teaching of subject areas ranging from social sciences to physical sciences included in geography itself. In this context, it has the qualifications that can be used in cases when human or many physical systems are to be addressed in relation to each other. At the same time, this subject is frequently underlined in the geography curriculum, and it was demanded to compare real events and situations with students for the explanations of the acquirements in the application suggestions. Thus, authentic learning practices with warnings and explanations became possible in the curriculum. The diversification of practices and the provision of feedback will provide clearer information on geography education.

\section{References}

Açıkgöz, K. Ü. (2004). Aktif Öğrenme. İzmir: Eğitim Dünyası Yayınları.

Akpınar, B. (2004). Konuşulan otantik bir dil kaynağı olarak televizyon reklamlarının yabancı dil öğretiminde kullanılması. Kuram ve Uygulamada Eğitim Yönetimi Dergisi, 38, 198-211.

Alacahan, G. (2016). Otantik öğrenmede yerel coğrafi bilgi ve halk takvimi (Unpublished master's thesis). Adnan Menderes Üniversitesi, Institute of Social Sciences, Aydın.

Bektaş, M., \& Horzum, B. (2010). Otantik Öğrenme. Ankara: Pegem Akademi Yayıncılık.

Brickell, G. J., \& Herrington, J. A. (2006). Scaffolding learners in authentic, problem-based e-learning environments: the geography challenge. Australasian Journal of Educational Technology, 22(4), 531-547. https://doi.org/10.14742/ajet.1284

Çalık, M., \& Sözbilir, M. (2014). İçerik Analizinin Parametreleri. Eğitim ve Bilim, 39(174), 33-38. https://doi.org/10.15390/EB.2014.3412

Cox, M., Ortmeier-Hooper, C., \& Tirabassi, K. E. (2009). Teaching writing for the "Real World: Community and workplace writing. The English Journal, 98(5), 72-80.

Demiralp, N. (2009). Haritalarla Öğrenme. Türk Eğitim Bilimleri Dergisi, 7(4), 955-973.

Dewey, J. (2010a). Günümüzde Eğitim (Ed. Joseph Ratner), (Bahri Ata, Talip Öztürk, çev.) Ankara: Pegem 
Akademi Yayıncilık.

Dewey, J. (2010b). Okul ve Toplum (H. Avni Başman, çev.), 2. Baskı. Ankara: Pegem Akademi Yayıncılık.

Dilmaç, O., \& Dilmaç, S. (2014). Lise öğrencilerinin görsel sanatlar dersinde otantik değerlendirme yaklaşımlarına yönelik görüşleri: Nitel bir araştırma. Uşak Üniversitesi Sosyal Bilimler Dergisi, 7(4), 275-298. https://doi.org/10.12780/UUSBD390

Fosnot, C. T. (2007). Constructivizm Oluşturmacılık Teori Perspektif ve Uygulama. 2.bask1. Ankara: Nobel Yayıncilik.

Göçmen, G. B. (2004). Otantik değerlendirme nedir ve nasıl yapılır? XIII. Ulusal Eğitim Bilimleri Kurultayı, 6-9 Temmuz 2004, İnönü Üniversitesi, Eğitim Fakültesi, Malatya.

Günay, R., \& Aydın, H. (2015). Türkiye’de Çok kültürlü Eğitim İle İlgili Yapılan Araştırmalarda Eğilim: Bir İçerik Analizi Çalışması. Eğitim ve Bilim, 40(178), 1-22. https://doi.org/10.15390/EB.2015.3294

Gürdoğan, M., \& Aslan, A. (2016). Sınıf öğretmeni adaylarının otantik öğrenme yaklaşımı hakkındaki görüşleri. Fen Bilimleri Ögretimi Dergisi, 4(2), 114-140.

Hillis, P., \& Calderhead, D. (2009). Helping to keep history relevant: Multimedia and authentic learning. Journal of Interactive Media in Education. https://doi.org/10.5334/2009-2

Horzum, M., \& Bektaş M. (2012). Otantik öğrenmenin topluma hizmet uygulamaları dersini alan öğretmen adaylarının derse yönelik tutum ve memnuniyetine etkisi. Kastamonu Eğitim Dergisi, 20(1), 341-360.

Huang, K.-H. (2011). Learning in authentic contexts: Projects integrating spatial technologies and fieldwork. Journal of Geography in Higher Education, 35(4), 565-578. https://doi.org/10.1080/03098265.2011.559577

İneç, Z. F., \& Akpınar, E. (2017). Sosyal bilgilerin otantik öğretiminde yeni yaklaşımlar. International Journal of Social Science Research, 6(2), 46-65.

Karabağ, S., \& Şahin, S. (2007). Kuram ve Uygulamada Coğrafya Ĕgitimi. Ankara: Gazi Kitapevi.

Karakuş, F. (2012). Oluşturmacı öğrenme ve otantik değerlendirme yaklaşımlarının sosyal bilgiler öğretiminde öğrencilerin akademik başarı ve kalıcılığa etkisi. Çukurova Üniversitesi Sosyal Bilimler Enstitüsü Dergisi, 21(1), 101-116.

Koçyiğit, S., \& Zembat, R. (2013). Otantik görevlerin öğretmen adaylarının başarılarına etkisi. Hacettepe Üniversitesi Eğitim Fakültesi Dergisi, 28(3), 291-303. https://doi.org/10.14686/BUEFAD.201416206

Kozikoğlu, İ., \& Senemoğlu, N. (2015). Eğitim Programları ve Öğretim Alanında Yapılan Doktora Tezlerinin İçerik Analizi (2009-2014). Eğitim ve Bilim, 40(182), 29-41. https://doi.org/10.15390/EB.2015.4784

Maina, F. W. (2004). Authentic learning: Perspectives from contemporary educators. Journal of Authentic Learning, 1, 1-8. Retrieved from http://hdl.handle.net/1951/389

Ministry of National Education (MoNE). (2005). Coğrafya Dersi Öğretim Programı. Ankara; Milli Ĕgitim Basımevi.

Ministry of National Education (MoNE). (2018). Coğrafya Dersi Öğretim Programı. Retrieved from http://mufredat.meb.gov.tr/ProgramDetay.aspx?PID=336

Newmann, F. M., \& Wehlage, G. G. (1993). Five standard of authentic instruction. Authentic Learning, 50(7), 8-12. Retrieved from http://www.ascd.org/publications/educational

Oliver, R., Herrington, J., Herrington, A., \& Reeves, T. C. (2007). Representing authentic learning designs supporting the development of online communities of learners. Journal of Learning Design, 2(2), 1-21. https://doi.org/10.5204/jld.v2i2.36

Öner, G. (2018). Yerel coğrafya ve öğretimi. Inönü Üniversitesi Eğitim Bilimleri Enstitüsü Dergisi, 5(9), $105-129$. https://doi.org/10.29129/inujgse.393951

Önger, S., \& Çetin, T. (2018). An investigation into digital literacy views of social studies preservice teachers in the context of authentic learning. Review of International Geographical Education Online (RIGEO), 8(1), 109-124.

Özçağlar A. (2000). Coğrafyaya Giriş. Ankara: Hilmi Usta Matbaacılık.

Özden, Y. (1996). Eğitimde yeniden yapılanma çerçevesinde otantik öğretim. Eğitim Yönetimi, 2(2), $270-277$.

Özey, R., \& İncekara, S. (2010). Coğrafya Ĕ̆itiminde Kavram ve Değişimler. Ankara: Pegem Akademi 
Yayıncilik.

Öztürk, M. (2007). Coğrafya: İçeriği, gelişimi, eğitimi. In S. Karabağ, \& S. Şahin (Eds.), Kuram ve Uygulamada Coğrafya Ĕ̈itimi (pp. 1-51). Ankara: Gazi Kitapevi.

Preus, B. (2012). Authentic instruction for 21 st century learning: higher order thinking in an inclusive school. American Secondary Education, 40(3), 59-79.

Quigley, C. (2014). Expanding our view of authentic learning: bridging in and out-of-school experiences. Cultural Studies of Science Education, 9(1), 115-122. https://doi.org/10.1007/s11422-013-9535-2

Rule, A. C. (2006). The components of authentic learning. Journal of Authentic Learning, 3(1), 1-10.

Slepkov, H. (2008). Teacher professional growth in an authentic learning environment. Journal of Research on Technology in Education, 41(1), 85-111. https://doi.org/10.1080/15391523.2008.10782524

Smeds, P., Jeronen, E., \& Kurppa, S. (2015). Farm education and the value of learning in an authentic learning environment. International Journal of Environmental \& Science Education, 10(3), 381-404.

Ünlü, M., \& Yıldırım, S. (2017). Coğrafya Dersi Öğretim Programına bir Coğrafi Beceri Önerisi: Mekansal Düşünme Becerisi. Marmara Coğrafya Dergisi, 35, 13-20. https://doi.org/10.14781/mcd.291018

Way, J. G., \& Eatough, D. L. (2008). Implementing an authentic research project on eastern coyotes at an urban high school. Cities and the Environment, 1(1), 1-13. https://doi.org/10.15365/cate.1152008

Webster-Wright, A. (2009). Reframing professional development through understanding authentic professional learning. Review of Educational Research, 79(2), 702-739. https://doi.org/10.3102/0034654308330970

Wilson, J. R., \& Schwier, R. A. (2009). Authenticity in the process of learning about instructional design. Canadian Journal of Learning and Technology, 35(2). https://doi.org/10.21432/T2DS3S

Yıldırım, A., \& Şimşek H. (2013). Sosyal Bilimlerde Nitel Araştırma Yöntemi. 9. baskı, Ankara: Seçkin Yayıncilik. 


\section{Appendix A}

\section{Inspected Articles Related to Authentic Learning}

\begin{tabular}{|c|c|}
\hline & Jame \\
\hline 1 & $\begin{array}{l}\text { Akpınar, B. (2004). Konuşulan otantik bir dil kaynağı olarak televizyon reklamlarının yabancı dil öğretiminde } \\
\text { kullanılması, Kuram ve Uygulamada Eğitim Yönetimi Dergisi, 38, 198-211. }\end{array}$ \\
\hline 2 & $\begin{array}{l}\text { orthwick, F., Bennett, S. Lefoe, G., Huber, E. (2007). Applying authentic learning to social science: A learning design } \\
\text { or an inter-disciplinary sociology subject, Journal of Learning Design, 2(1), 14-24. }\end{array}$ \\
\hline 3 & $\begin{array}{l}\text { Boyacı, Ş.D.B., Güner, M. (2017). Türkçe dersinde teknolojik otantik ortamın kullanılmasına dair öğrenci ve öğretmen } \\
\text { örüșleri, Anadolu Journal of Educational Sciences International, 7(1), 35-71. }\end{array}$ \\
\hline 4 & $\begin{array}{l}\text { 3rickell, G. J. and Herrington, J. A. (2006). Scaffolding learners in authentic, problem-based e-learning environments: } \\
\text { he geography challenge, Australasian Journal of Educational Technology, } 22 \text { (4), 531-547. }\end{array}$ \\
\hline 5 & $\begin{array}{l}\text { Cox, M., Ortmeier-Hooper, C. and Tirabassi, K.E. (2009). Teaching writing for the "Real World": Community and } \\
\text { vorkplace writing, The English Journal, } 98 \text { (5), 72-80. }\end{array}$ \\
\hline 6 & $\begin{array}{l}\text { Dilmaç, O. and Dilmaç, S. (2014). Lise öğrencilerinin görsel sanatlar dersinde otantik değerlendirme yaklaşımlarına } \\
\text { önelik görüșleri: Nitel bir araştırma, Uşak Üniversitesi Sosyal Bilimler Dergisi, 7/4, 275-298. }\end{array}$ \\
\hline 7 & $\begin{array}{l}\text { ïrdoğan, M. and Aslan, A. (2016). Sınıf öğretmeni adaylarının otantik öğrenme yaklaşımı hakkındaki görüşleri, Fen } \\
\text { ilimleri Öğretimi Dergisi, } 4 \text { (2), 114-140. }\end{array}$ \\
\hline 8 & $\begin{array}{l}\text { Hillis, P. and Calderhead, D. (2009). Helping to keep history relevant: Multimedia and authentic learning, Submission } \\
\text { to Journal of Interactive Media in Education, } 1-18 \text {. http://jime.open.ac.uk/2009/02/jime-2009-02.html }\end{array}$ \\
\hline 9 & $\begin{array}{l}\text { Horzum, M. and Bektaş M. (2012). Otantik öğrenmenin topluma hizmet uygulamaları dersini alan öğretmen } \\
\text { adaylarının derse yönelik tutum ve memnuniyetine etkisi, Kastamonu Eğitim Dergisi, } 20 \text { (1), 341-360. }\end{array}$ \\
\hline 10 & $\begin{array}{l}\text { Huang, K.H. (2011). Learning in authentic contexts: Projects integrating spatial technologies and fieldwork, Journal of } \\
\text { Geography in Higher Education, } 35 \text { (4), 565-578. }\end{array}$ \\
\hline 11 & $\begin{array}{l}\text { neç, Z.F. and Akpınar, E. (2017). Sosyal bilgilerin otantik öğretiminde yeni yaklaşımlar, International Journal Of } \\
\text { Social Science Research, } 6 \text { (2), 46-65. }\end{array}$ \\
\hline 12 & $\begin{array}{l}\text { Karakuş, F. (2012). Oluşturmacı öğrenme ve otantik değerlendirme yaklaşımlarının sosyal bilgiler öğretiminde } \\
\text { ögrencilerin akademik başarı ve kalıcılığa etkisi, Cukurova Üniversitesi Sosyal Bilimler Enstitüsï Dergisi, 21 (1), 101- } \\
116 .\end{array}$ \\
\hline 13 & $\begin{array}{l}\text { Koçyiğit, S. and Zembat, R. (2013). Otantik görevlerin öğretmen adaylarının başarılarına etkisi, Hacettepe } \\
\text { Üniversitesi Eğitim Fakültesi Dergisi, } 28 \text { (3), 291-303. }\end{array}$ \\
\hline 14 & $\begin{array}{l}\text { Maina F.W. (2004). Authentic learning: Perspectives from contemporary educators, Journal of Authentic Learning, } 1 \text {, } \\
\text { 1-8. }\end{array}$ \\
\hline 15 & $\begin{array}{l}\text { Moffett, P. (2012). Learning about outdoor education through authentic activity, Journal of the Association of Teachers } \\
\text { of Mathematics Mathematics Teaching, 227, 12-14. }\end{array}$ \\
\hline 16 & J.G.( 1993). Five standart of authentic instruction, Authentic Learning, 50(7), 8-12 \\
\hline 17 & $\begin{array}{l}\text { iver, R., Herrington, J., Herrington, A. and Reeves, T.C. (2007). Representing authentic learning designs supporting } \\
\text { development of online communities of learners, Journal of Learning Design, 2(2), 1-21. }\end{array}$ \\
\hline 18 & $\begin{array}{l}\text { ner, G. (April 2018). Yerel coğrafya ve öğretimi, Inönü Üniversitesi Eğitim Bilimleri Enstitüsü Dengisi, 5(9), 105- } \\
\text { 29. }\end{array}$ \\
\hline 19 & $\begin{array}{l}\text { Önger, S. and Cetin, T. (2018). An investigation into digital literacy views of social studies preservice teachers in the } \\
\text { context of authentic learning, Review of International Geographical Education Online (RIGEO), } 8(1), 109-124 .\end{array}$ \\
\hline 20 & $\begin{array}{l}\text { Preus B. (2012). Authentic instruction for } 21 \text { st century learning: higher order thinking in an inclusive school, } \\
\text { American Secondary Education, } 40 \text { (3) 59-79. }\end{array}$ \\
\hline 21 & le, A. C. (2006). Editorial: The components of authentic learning, Journal of Authentic Learning, 3(1), 1-10. \\
\hline 22 & $\begin{array}{l}\text { lepkov, H. (2008). Teacher professional growth in an authentic learning environment, Journal of Research on } \\
\text { echnology in Education, } 41(1), 85-111 \text {. }\end{array}$ \\
\hline 23 & $\begin{array}{l}\text { Smeds, P., Jeronen, E. and Kurppa, S. (2015). Farm education and the value of learning in an authentic learning } \\
\text { environment, International Journal of Environmental \& Science Education, } 10 \text { (3), 381-404. }\end{array}$ \\
\hline 24 & $\begin{array}{l}\text { Quigley, C. (2014). Expanding our view of authentic learning: bridging in and out-of-school experiences, Cultural } \\
\text { Studies of Science Education, } 9 \text { (1), 115-122. }\end{array}$ \\
\hline 25 & $\begin{array}{l}\text { Way, J.G. and Eatough, D.L. (2008) Implementing an authentic research project on eastern coyotes at an urban high } \\
\text { school, Cities and the Environment, } 1(1), 1-13 \text {. }\end{array}$ \\
\hline 26 & $\begin{array}{l}\text { Westberg, K.L. and Leppien, J. H. (2018). Student independent investigations for authentic learning, Gifted Child } \\
\text { Today, 41(1), 13-18. }\end{array}$ \\
\hline 27 & $\begin{array}{l}\text { Wilson, J.R. and Schwier, R.A. (2009). Authenticity in the process of learning about instructional design, Canadian } \\
\text { Journal of Learning and Technology, 35(2), 1-15. }\end{array}$ \\
\hline 28 & $\begin{array}{l}\text { Webster-Wright, A. (2009). Reframing professional development through understanding authentic professional } \\
\text { learning, Review of Educational Research, } 79 \text { (2), 702-739. }\end{array}$ \\
\hline
\end{tabular}




\section{Appendix B}

\section{Theses and Related Fields with Authentic Learning in Turkey}

\begin{tabular}{|c|c|}
\hline 1 & $\begin{array}{l}\text { zanc1, H. (2010). Otantik öğrenme açısından yerel coğrafi bilgi (Artova örneği), (Yayınlanmamış } \\
\text { sek lisans tezi) Gaziosman Paşa Üniversitesi Sosyal Bilimler Enstitüsü, Tokat. }\end{array}$ \\
\hline 2 & $\begin{array}{l}\text { oçyiğit, S. (2011). Otantik görev odakl yapılandırmacı yaklaşımın öğretmen adaylarının başarılarına, } \\
\text { rse karşı tutumlarına ve problem çözme becerilerine etkisi, (Yayınlanmamış Doktora tezi) Marmara } \\
\text { niversitesi Eğitim bilimleri Enstitüsü, İstanbul. }\end{array}$ \\
\hline 3 & $\begin{array}{l}\text { astürk, G.Y. (2013). Öğretmen adaylarının bazı çevre konularına ilişkin zihinsel yapılarındaki } \\
\text { ’ğişimlerin otantik öğrenme ortamlarında incelenmesi ve değerlendirilmesi, (Yayınlanmamış doktora } \\
\text { zi). Gazi Üniversitesi Eğitim Bilimleri Enstitüsü, İstanbul. }\end{array}$ \\
\hline 4 & $\begin{array}{l}\text { aman, M. (2014). Exploration of English as a foreign language students' perceptions about online } \\
\text { thentic readings, (Unpublished Master's thesis). ODTÜ Sosyal Bilimler Enstitüsü, Ankara. }\end{array}$ \\
\hline 5 & $\begin{array}{l}\text { ürdoğan, M. (2014). Sınıf öğretmeni adaylarının otantik öğrenme yaklaşımının uygulanabilirliği ile ilgili } \\
\text { irüssleri: Fen ve teknoloji laboratuvar uygulaması örneği, (Yayınlanmamış yüksek lisans tezi). Akdeniz } \\
\text { niversitesi Eğitim Bilimleri Enstitüsü, Antalya. }\end{array}$ \\
\hline 6 & $\begin{array}{l}\text { lapçığlu, S.D. (2015). Matematik dersinde otantik öğrenme yoluyla eleştirel düşünme becerisinin } \\
\text { lişstirilmesi: Bir eylem araştırması, (Yayınlanmamış doktora tezi). Çukurova Üniversitesi Sosyal Bilimler } \\
\text { stitüsü, Adana. }\end{array}$ \\
\hline 7 & $\begin{array}{l}\text { nay, İ. (2015). Otantik değerlendirme yaklaşımının öğretmen adaylarının problem çözme becerileri ile } \\
\text { renmeye ve katılımcı değerlendirmeye yönelik inançlarına etkisinin incelenmesi, (Yayınlanmamı̧̧ } \\
\text { ktora tezi). Gaziantep Üniversitesi Eğitim Bilimleri Enstitüsü, Gaziantep. }\end{array}$ \\
\hline 8 & $\begin{array}{l}\text { ri becerilerini ölçen çoktan seçmeli, otantik ve simülasyon } \\
\text { renci görüsleri, (Yayınlanmamış yüksek lisans tezi). Uludağ }\end{array}$ \\
\hline 9 & $\begin{array}{l}\text { u, G.C. (2016). İlköğretim 7. sinıf Türkçe dersinde otantik öğrenmenin öğrencilerin problem çözme } \\
\text { luğunu anlama becerileri ile derse ilişkin tutumlarına etkisi, (Yayınlanmamış doktora tezi). İnönü } \\
\text { itesi Eğitim Bilimleri Enstitüsü, Malatya. }\end{array}$ \\
\hline 10 & $\begin{array}{l}\text { ilgin, C.U. (2016). Facilitating english as a foreign language learners' vocabulary learning, task } \\
\text { ompletion and contextual vocabulary expioration processes in a mobile supported situated learning } \\
\text { svironment, (Yayınlanmamış doktora tezi). Department of Computer Education and Instructional } \\
\text { echnology, METU, Ankara. }\end{array}$ \\
\hline 11 & $\begin{array}{l}\text { Y. (2016). Ö̆rretim ilke ve yöntemleri dersine yönelik okul temelli bir ögretim programı gelistirme } \\
\text { (Yayınlanmamış doktora tezi). Çukurova Üniversitesi Eğitim Bilimleri Enstitüsü, Adana. }\end{array}$ \\
\hline 12 & in incelenmesi, \\
\hline 13 & $\begin{array}{l}\text { tantik materyal kullanımının ögrencilerin } \\
\text { üzerindeki etkisi, (Yayınlanmamış yüksek } \\
\text { kişehir. }\end{array}$ \\
\hline 14 & $\begin{array}{l}\text { Matematik dersinde otantik görev odakl öğrenme süreçlerinin incelenmesi: Bir eylem } \\
\text { ınlanmamıș doktora tezi). Gaziantep Üniversitesi Eğitim Bilimleri Enstitüsü, Gaziantep. }\end{array}$ \\
\hline 15 & $\begin{array}{l}\text { lat, Y. (2016). Kavram temelli disiplinler arası yaklaşıma göre tasarlanan ünitenin otantik } \\
\text { gerlendirmesine yönelik bir eylem araştırması, (Yayınlanmamış doktora tezi). Çukurova Üniversitesi } \\
\text { jitim Bilimleri Enstitüsü, Adana. }\end{array}$ \\
\hline 16 & $\begin{array}{l}\text { 7). Sosyal bilgiler dersinde geo-medya destekli otantik ögrenme ortamının ögrenmeye etkisi, } \\
\text { 1ș doktora tezi). Erzincan Üniversitesi Sosyal Bilimler Enstitüsü, Erzincan. }\end{array}$ \\
\hline 17 & $\begin{array}{l}\text { Dadl, G. (2017). Insan ve çevre ilişkileri ünitesinde otantik probleme dayalı öğrenme etkinliklerinin } 7 . \\
\text { stnıf öğrencilerinde yansittcı düsünme becerisi, akademik başarı, çevre tutum ve farkındalıkları üzerine } \\
\text { etkisi, (Yayınlanmamış yüksek lisans tezi). Sütçü İmam Üniversitesi Fen Bilimleri Enstitüsü, } \\
\text { Kahramanmaraş. }\end{array}$ \\
\hline 18 & $\begin{array}{l}\text { Gündoğan, A. (2017). Hayat bilgisi dersinde otantik görev temelli öğrenme ortamlarının ögrencilerin } \\
\text { derse yönelik tutumlarına ve ögrenme süreçlerine yansımasl, (Yayınlanmamış doktora tezi). Anadolu } \\
\text { Üniversitesi Eğitim Bilimleri Enstitüsü, Eskişehir. }\end{array}$ \\
\hline 19 & $\begin{array}{l}\text { Gürbüz, M.K. (2018). Yedinci sınıf öğrencilerinin etkinlik temelli ögrenme yaklaşımı altında oran-orantı } \\
\text { kavramların oluşturma süreçlerinin incelenmesi: APOS teorisi, (Yayınlanmamış yüksek lisans tezi). } \\
\text { Eskksehir Osmangazi Üniversitesi Eăitim Bilimleri Enstitüsü. Eskisehir. }\end{array}$ \\
\hline
\end{tabular}




\section{Copyrights}

Copyright for this article is retained by the author(s), with first publication rights granted to the journal.

This is an open-access article distributed under the terms and conditions of the Creative Commons Attribution license (http://creativecommons.org/licenses/by/4.0/). 